\title{
New taxa and phyletic evolution of the Aeronian (Llandovery, Silurian) Petalocrinidae (Echinodermata, Crinoidea) in Guizhou, South China Block
}

\author{
Yingyan Mao, ${ }^{1,2}$ William I. Ausich, ${ }^{3}$ Yue Li, ${ }^{1} *$ Jih-Pai Lin, ${ }^{4}$ and Caihua $\operatorname{Lin}^{5}$ \\ ${ }^{1}$ Key Laboratory of Economic Stratigraphy and Paleogeography, Nanjing Institute of Geology and Paleontology, Chinese Academy of Sciences, \\ Nanjing 210008, China 〈yymao@ nigpas.ac.cn〉, 〈yueli@nigpas.ac.cn〉 \\ ${ }^{2}$ University of the Chinese Academy of Sciences, Beijing 100049, China \\ ${ }^{3}$ School of Earth Sciences, The Ohio State University, Columbus, OH 43210, USA 〈ausich.1@ osu.edu〉 \\ ${ }^{4}$ Department of Geosciences, National Taiwan University, No. 1, Sec. 4, Roosevelt Road, Taipei 106, Taiwan 〈jplin@ hotmail.com〉 \\ ${ }^{5}$ Library and Information Center, Nanjing Institute of Geology and Paleontology, Chinese Academy of Sciences, Nanjing 210008, China \\ $\langle$ chlin@nigpas.ac.cn〉
}

\begin{abstract}
Systematic paleontology of three new species of Petalocrinidae (Crinoidea) are documented from the carbonate-dominated units of the Shihniulan and equivalent Leijiatun formations (Llandovery, Silurian) of the Baisha, Fengxiang, and Shuibatang sections in Guizhou (China). New taxa are from the Upper Yangtze Epicontinental Sea of the South China Block. The new taxa include Petalocrinus stenopetalus new species, Spirocrinus circularis new species, and $S$. dextrosus new species. They have a narrow spatial and temporal (Aeronian) distribution. Evolutionary patterns of the four genera of Petalocrinidae are outlined based on the specialized characters of the fused arm plates. Phylogenetic analysis was used to assess morphological relationships within the Petalocrinidae. Petalocrinus inferior represents the plesiomorphic condition for the group and nests as a sister group of P. stenopetalus $\mathrm{n}$. sp. and the Spirocrinus species used in this analysis and the clade exclusively comprised of Sinopetalocrinus. The phylogenetic analysis suggests that Petalocrinus, as currently defined, might be a paraphyletic genus.
\end{abstract}

\section{Introduction}

Research on Silurian Petalocrinidae began more than one century ago with studies in Iowa (Weller and Davidson, 1896) and Sweden (Bather, 1898). The key defining feature for the family is the presence of fused arm plates. The stratigraphic range of the Petalocrinidae is from Middle Ordovician $(\mathrm{Li}$, 1993) to Early Devonian (Prokop, 1983 [1984]; Prokop and Petr, 2010). The oldest representative is Eopetalocrinus sinensis from the Dapingian (Middle Ordovician) Dawan Formation at the Songzi section, Hubei Province (Li, 1993). Petalocrinidae are not known from Darriwilian (late Middle Ordovician) through the Llandoverian (earliest Silurian) in China, but they became geographically widespread during the Llandovery. The youngest occurrence of the family is the Early Devonian Vadarocrinus from the Czech Republic (Prokop, 1983 [1984]). This family flourished during the Llandovery and Wenlock. Systematic study of early Silurian crinoids advanced considerably beginning in the 1980s with faunas reported from Iowa (Witzke and Strimple, 1981), Ohio (Ausich, 1984a, b, 1985, 1986a, b, c, d, 1987a, b; Ausich and Dravage, 1988; Boyarko and Ausich, 2009), Kentucky (Ausich et al., 2015), New York and Canada (e.g., Eckert, 1984, 1990; Eckert and Brett, 2001; Ausich and Copper, 2010), and Britain and Ireland (e.g., Donovan and Sevastopulo, 1989; Donovan, 1993;

* Corresponding author
Donovan and Harper, 2003; Donovan and Lewis, 2005; Fearnhead and Donovan, 2007a, b; Fearnhead and Harper, 2007; Donovan et al., 2008, 2009, 2010, 2012). All Silurian Petalocrinidae in China are from the Upper Yangtze Epicontinental Sea, South China Block. They have been identified as three genera, Petalocrinus, Spirocrinus, and Sinopetalocrinus (Mu, 1949 [1950]; Tien and $\mathrm{Mu}, 1955 ; \mathrm{Mu}$ and $\mathrm{Wu}, 1974$; Mu and Lin, 1987; Chen and Yao, 1993). Mao et al. (2015) summarized the geographic and temporal distribution of the Petalocrinidae, including 28 species belonging to five genera; and they hypothesized that the Upper Yangtze Epicontinental Sea was the center for the Ordovician origination and Silurian diversification of genera for this most unusual family.

We found new material from three sections of the upper Aeronian (Llandovery, Silurian) units, Shihniulan and Leijiatun formations (updated stratigraphic correlation following biozonations by Rong and Chen, 2000; Rong et al., 2003), during four years of recent field excursions (Fig. 1). In the present paper, one new species of Petalocrinus and two new species of Spirocrinus are described. Based on their morphology, phylogenetic relationships among the Petalocrinidae genera are proposed.

\section{Geological setting}

The Upper (today, western) Yangtze region of the South China Block was covered by an epicontinental sea with a southward extension of the Qianzhong Oldland during the Silurian. After the 

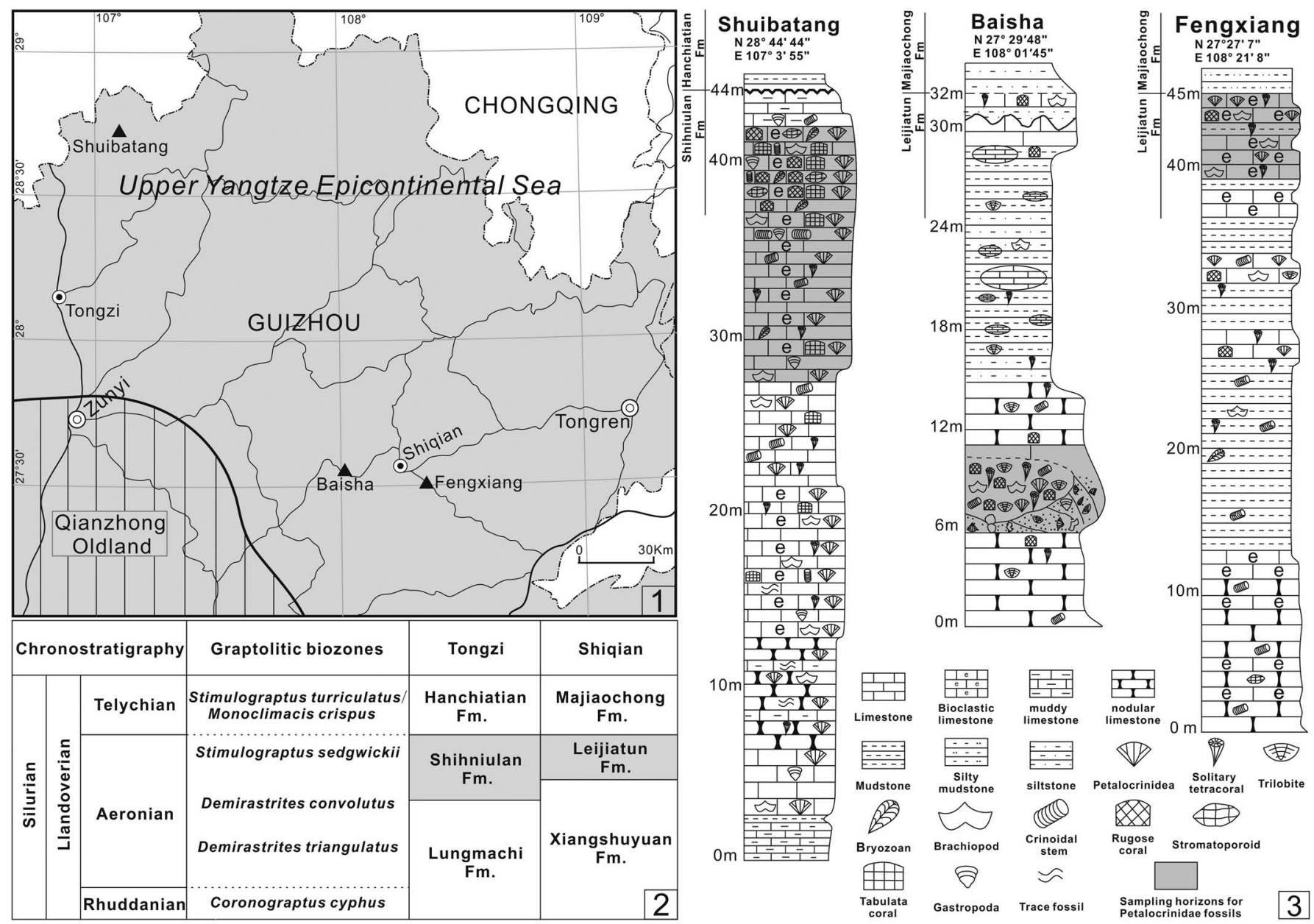

Figure 1. (1) Locations of study sections for the present paper with their paleogeographic position on the Upper Yangtze Epicontinental Sea, base map after Rong et al., 2003. (2) Biostratigraphic position of the Petalocrinidae-bearing units of the Shihniulan and Leijiatun formations (after Chen et al., 1996). (3) Lithological sequences of the Petalocrinidae-bearing units from where specimens have been collected. The shaded region in each section indicates the horizons where Petalocrinidae occur.

end-Ordovician glacial episode, rising sea level during the earliest Silurian resulted in the shelly Hirnantia fauna of the Kuanyinchiao Formation, which was largely rapidly replaced by graptolitic black shales of the Lungmachi Formation. Terrigenous sedimentation dominated the Llandovery sequences, except for rich bioclastic limestones of the upper Aeronian (e.g., Rong et al., 2003). Silts and bioclastic limestones and upward reefal units of the Rhuddanian-middle Aeronian Xiangshuyuan Formation were restricted to very narrow near-shore belts (e.g., Yang et al., 2002; Guo et al., 2004; Rong and Zhan, 2004; Ma et al., 2006; Ni et al., 2015; Wang et al., 2015). Upper Aeronian units are predominantly comprised of shallow-marine limestones with less argillaceous material due to the gradual regressive sequences. Shelly faunas, including brachiopods, corals, stromatoporoids, cephalopods, and crinoids, have high diversity and abundance from both reef and bank facies of the Shihniulan and coeval Leijiatun formations (e.g., Li et al., 2004; Wang et al., 2014).

Known Silurian Petalocrinidae material from the South China Block is limited to the Upper Yangtze Epicontinental Sea spatially and temporally to equivalent units of the Shihniulan Formation in northern Guizhou, the Leijiatun Formation in northeastern Guizhou, and the Lojoping Formation in western
Hubei. Although, species richness and abundance of fossils are quite uneven from place to place, petalocrinids are notably abundant in the ramp settings in sections north of the Qianzhong Oldland. In contrast, their occurrences in outer-shelf facies are extremely low. Among the Petalocrinidae, Petalocrinus has the widest distribution both in China and globally. Other older genera are from the Shihniulan and equivalent Leijiatun formations. Therefore, Aeronian sequences in Guizhou have potential to increase the biodiversity of the family (Mao et al., 2015).

The late Aeronian Petalocrinidae specimens studied herein were collected from reef and bank facies. Sampling horizons are shown in the stratigraphic columns of Figure 1 and are from a reef flank at Shuibatang (subfacies described by Wang et al., 2014), talus of a patch reef at Baisha (subfacies described by $\mathrm{Li}$ and Kershaw, 2003), and a shelly bank at the Fengxiang sections.

As noted above, knowledge of early Silurian crinoids worldwide has been greatly expanded since 1980 . The Petalocrinidae faunas reported here are late Aeronian in age and approximately coeval with several now well-known faunas in North America and Western Europe. These include the following faunas from North America: Bear Creek Shale, New York (Eckert and Brett, 2001); 
Brassfield Formation, Ohio and Kentucky (various publications noted above); the East Point, Goéland, and Richardson members of the Jupiter Formation, Quebec (Ausich and Copper, 2010); the La Chute and Mc Giluray members of the Gun River Formation, Quebec (Ausich and Copper, 2010); and the Hickory and Wallington members of the Reynales Formation, New York (Eckert, 1990; Eckert and Brett, 2001). In the United Kingdom, this new fauna is approximately equivalent to the Mulloch Hill Sandstone, Scotland (Fearnhead and Donovan, 2007a, 2007b).

\section{Materials and methods}

The specimens described herein were collected from the Shuibatang, Baisha, and Fengxiang sections. 13 specimens were collected from the Shuibatang section, including the holotypes of Spirocrinus circularis n. sp. and Spirocrinus dextrosus n. sp.; seven specimens were from the Baisha section, including Petalocrinus inferior with all the arms intact, and the holotype Petalocrinus stenopetalus $\mathrm{n}$. sp.; and three specimens were from the Fengxiang section. In addition, thirteen specimens from Mu and Lin (1987) are illustrated herein, including two specimens of Petalocrinus inferior and 11 type specimens of Sinopetalocrinus.

The phylogenetic analysis presented here was completed in PAUP 4.0a142 (Swofford, 2002) using the maximum parsimony criterion. All characters were equally weighted and unordered, and a heuristic search with the tree-bisection reconnection (TBR) algorithm was conducted with random addition repeated 1000 times. A 50\% majority-rule tree with bootstrap values is presented. The consistency index $(\mathrm{CI})$, retention index (RI), and rescaled-consistency index (RC) are listed. Bootstrap and jackknife support were also calculated in PAUP 4.0a142.

As noted elsewhere, the oldest known petalocrinid is Eopetalocrinus from the Ordovician of China, and all other studied taxa are from the Llandovery (Aeronian) of China. Thus, Eopetalocrinus is used as the outgroup. All but one of the taxa considered in this study are known exclusively from the second primibrachial plate. Although the brachial plates among petalocrinids have distinctive characteristics, with only eleven second primibrachial characters known (Appendices 1 and 2) to delineate relationships among nine taxa, a highly resolved tree should not be expected. Thus, we illustrate the $50 \%$ majority-rule tree with bootstrap and jackknife values.

Terminology and classification follows Weller and Davidson (1896), Bather (1898), Lane and Moore (1978), Mu and Lin (1987), and Mao et al. (2015). All measurements are in mm (millimeters).

Repository and institutional abbreviation.-All specimens are deposited in the Nanjing Institute of Geology of Paleontology, Chinese Academy of Sciences (NIGP). Specific locations are listed in the occurrence sections for each species (see below).

\section{Systematic paleontology}

Class Crinoidea Miller, 1821

Subclass Cladida Moore and Laudon, 1943

Order Cyathocrinina Bather, 1899
Superfamily Gasterocomacea Roemer, 1854

Family Petalocrinidae Weller and Davidson, 1896

Remarks.-According to Mao et al. (2015), the Petalocrinidae has a relatively small aboral cup with arms, each presumably a series of fused brachials. These specialized arm plates are robust and can be transported as isolated plates after death. Although relatively common in many settings, very few specimens of any petalocrinid are known from the entire crown. Instead, their fossil record is almost entirely known from the large fused secundibrachial plates. Thus, the genera and species of the Petalocrinidae are based on the morphology of fused arm plates instead of aboral cup plates (Fearnhead and Donovan, 2007a), which is unusual among crinoids. In the few specimens preserved with complete crowns, the second primibrachial characters are consistent within an individual. Therefore, until demonstrated otherwise, one must assume that arm characters are consistent within an individual and within a taxon. Despite the fact that only second secundibrachials are evaluated and relatively few characters can be identified to differentiate among taxa, the characters that do exist are varied, distinctive, and directly linked to suspension-feeding behavior. So, the second primibrachials provide critical information about these crinoids.

The Ordovician to Devonian family Petalocrinidae includes 28 species belonging to five genera. Paleobiogeographic occurrences of this family include Laurentia, Baltica, Avalonia, South China, Sibumasu, and Perunica blocks. Among these, the South China Block contains the most diversified forms during the Llandovery.

\section{Genus Petalocrinus Weller and Davidson, 1896}

Type species.-Petalocrinus mirabilis Weller and Davidson, 1896.

Other species._Petalocrinus inferior Bather, 1898.

\section{Petalocrinus inferior Bather, 1898}

Figure 2

$1898 \quad$ Petalocrinus inferior Bather, p. 426, pl. 26, fig. 57.

1949 (1950) Petalocrinus inferior; Mu, p. 94, pl. 3, figs. 1-3, 12. 1955 Petalocrinus inferior; Tien and $\mathrm{Mu}, \mathrm{p} .91-92$, pl. 48, figs. 6-10.

1987 Petalocrinus inferior; $\mathrm{Mu}$ and Lin, p. 7-8, pl. 1, figs. 1-2.

Occurrence.-Leijiatun Formation, Aeronian (Llandovery, Silurian), Sigou section, Shiqian County, Guizhou Province, China; Leijiatun Formation, Aeronian (Llandovery, Silurian), Baisha section, Shiqian County, Guizhou Province, China.

Materials.-NIGP 73928, NIGP 73929, and NIGP 163722.

Remarks.-NIGP 73928 and NIGP 73929 are two scattered arm plates from $\mathrm{Mu}$ and Lin (1987). NIGP 163722 is the first specimen known from the Upper Yangtze Platform, South China Block with all the arms intact. The entire specimen is 

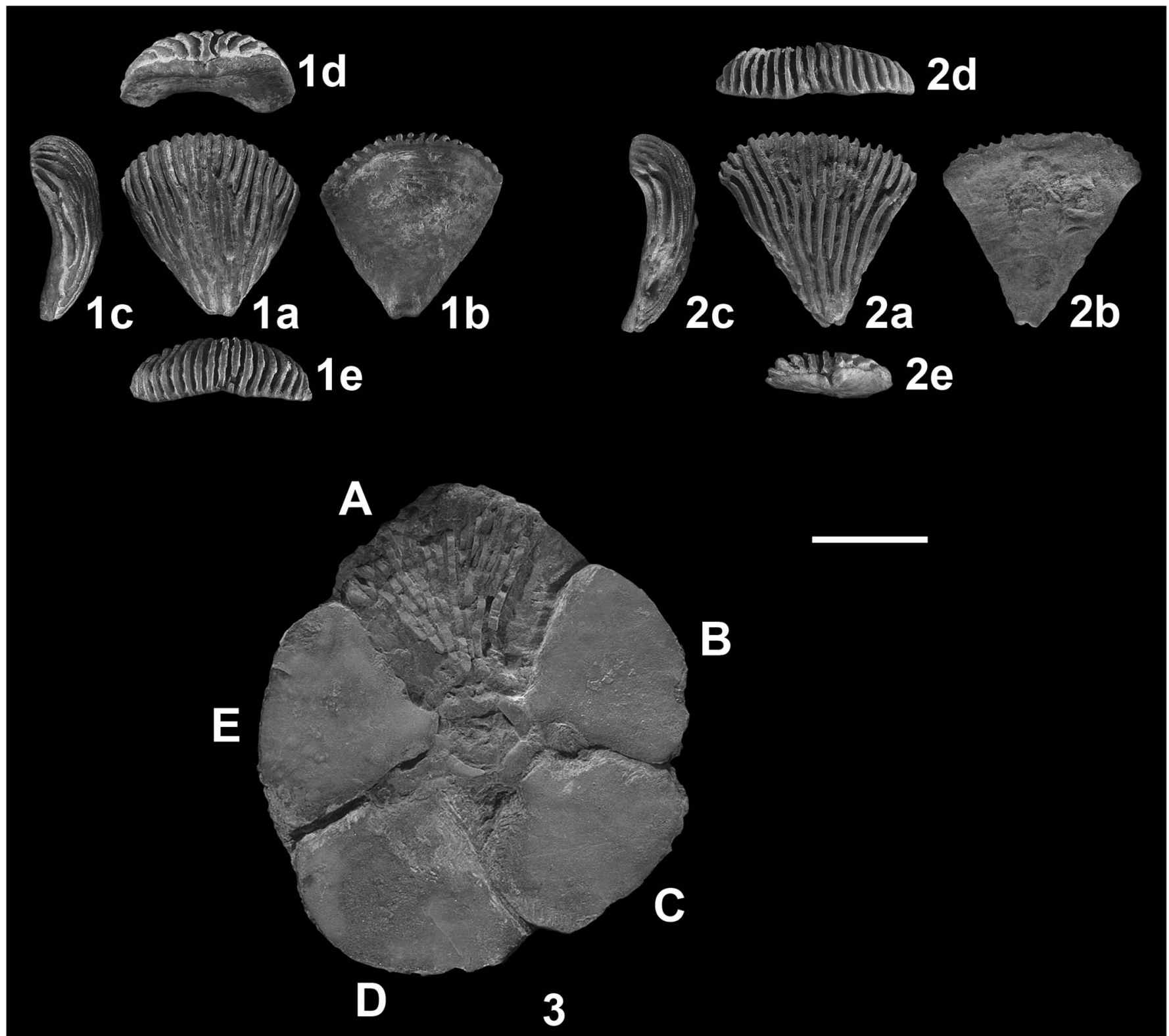

Figure 2. Petalocrinus inferior: (1-2) Mu and Lin, 1987, NIGP 73928, NIGP 73929; a, oral side of arm plate; b, aboral side of arm plate; c, lateral view of arm plate; $\mathrm{d}$, front view of distal furrows; e, facet view of arm plate; (3) NIGP 163722, complete specimen showing the aboral view of a crown. Scale bar $=1 \mathrm{~cm}$.

flattened with the five arms articulated as during life, and only the aboral side of the crown is exposed. The aboral cup is bowl shaped, but the proximal part of the infrabasals and basals are weathered away to reveal only a subpentagonal outline. The B, C, D, and E radials are partly weathered, subequal, and subtriangular in shape. The aboral portion of the A arm is weathered to expose the ambulacral grooves. The sutures of the small cup are fairly distinct; diameter of calyx is $9 \mathrm{~mm}$.

One first primibrachial is present and rests on the E radial facet with its proximal and distal margins parallel. The proximal width of the first primibrachial is $3 \mathrm{~mm}$ and the height is $0.5 \mathrm{~mm}$, with the same thickness on both proximal and distal margins. The first primibrachials are not clearly preserved in the other four rays, but the small gap between the facet and the arm fan suggests the existence of first primibrachials that are weathered away or covered.
The angle of the subtriangular fused arm is defined as the angle between lines drawn parallel to the general direction of the diverging sides, exclusive of the incurved distal region (Bather, 1898). The arm angles are $\mathrm{B}, 90^{\circ} ; \mathrm{C}, 105^{\circ} ; \mathrm{D}, 87^{\circ}$, and $\mathrm{E}, 95^{\circ}$, with an average in these four arms of $94^{\circ}$. Fine-grained sculpturing is poorly preserved on the aboral side of the four better-preserved arms. The A arm is deeply weathered to expose the weathered ambulacral grooves and ridges separating adjacent ambulacral grooves. Sixteen ambulacral grooves are on the distal margin of the A arm. NIGP 163722 illustrates that the five arms of an individual differ in their angles.

\section{Petalocrinus stenopetalus new species} Figure 3

Holotype.-Holotype NIGP 163723. 
Diagnosis.-Horseshoe-shaped articular facets; fused brachials planate; fan bilaterally symmetrical in shape and arrangement of grooves; fused brachials expand in width rapidly for short distance, then are parallel-sided for most of the length for long distance; distal arms with a convex margin; as many as 6-8 distal ambulacra, adjacent arms not in lateral contact; ambulacral grooves rectilinear and only on oral surface; arm angles are $30^{\circ}-60^{\circ}$.

Occurrence.-Leijiatun Formation, Aeronian (Llandovery, Silurian), Baisha section, Shiqian County, Guizhou, China.

Description.-Narrow, planate, and slender fused arms. Ambulacral grooves divide almost immediately on the proximal arm, yielding two similar halves. Fused brachials expand in width rapidly for short distance, then are parallel-sided for most of the length for long distance, distal arms with a convex margin. NIGP 163723-163725 are relatively larger than NIGP 163726-163728. Arm height, of NIGP 163723-163725 is respectively $30.4 \mathrm{~mm}, 32.7 \mathrm{~mm}$, and $26.9 \mathrm{~mm}$; and that of NIGP $163726-163728$ is $12.0 \mathrm{~mm}, 11.0 \mathrm{~mm}$, and $21.8 \mathrm{~mm}$, respectively. The maximum width of NIGP 163723-163725 respectively is $7.0 \mathrm{~mm}, 7.5 \mathrm{~mm}$, and $5.8 \mathrm{~mm}$; and that of NIGP $163726-163728$ is $4.9 \mathrm{~mm}, 5.9 \mathrm{~mm}$, and $9.0 \mathrm{~mm}$, respectively. Thickest parts of the six specimens are from $2.6-4.3 \mathrm{~mm}$.

The arm plates of the six specimens have perfect bilateral symmetry. The ambulacral grooves on each arm branch exotomously no more than three times, with no branching in the middle part of arm fan yielding 6-8 ambulacral grooves on the distal margin. NIGP 163723-163725, 163727, and 163728 branch three times with eight ambulacra, respectively, and NIGP 163726 branches two times with six finals. Ambulacral grooves rectilinear and are only on oral surface. Width of the ambulacral grooves $\sim 1 \mathrm{~mm}$; clear notches for ambulacral cover plates (NIGP 163723, NIGP 163724). Width of the ridge equal to that of ambulacral grooves, flat ridge top.

Well-preserved horseshoe-shaped arm facet in NIGP $163723,163725-163727$ with the width between $1.4 \mathrm{~mm}$ and $3.0 \mathrm{~mm}$ and a depth of facet $1.0-2.6 \mathrm{~mm}$.

Etymology.-The species name 'stenopetalus' recognizes the species of Petalocrinus with the narrowest arms.

Materials.-Paratypes NIGP 163724 and NIGP 163725; other materials: NIGP 163726-163728.

Remarks.-Six specimens of Petalocrinus stenopetalus $\mathrm{n}$. sp. include: (1) adult specimens, NIGP 163723-163725, 163727, and 163728; and (2) a juvenile specimen, NIGP 163726, which is relatively small and has fewer branches and finals.

This new species is significant for understanding evolutionary trends of Petalocrinus. The arms of P. stenopetalus n. sp. are narrow and elongate with a minimum width and the fewest number of ambulacral grooves. Other species of Petalocrinus typically have subtriangular plates that commonly have more than ten grooves and the arm ratio of height/ maximum width not exceeding two. In contrast, $P$. stenopetalus n. sp. has eight or fewer distal ambulacra and very elongate arms.
The arm plates of the six specimens are perfectly bilateral symmetrical. The ambulacral grooves on each arm branch exotomously as many as three times, yielding eight ambulacra on the distal margin in adult specimens. After the third ambulacral branch, the width of arms does not increase. NIGP 163726 is a juvenile specimen (Fig. 3.4) with six ambulacral grooves, whereas adults have eight ambulacral grooves. Thus, a general indication of the growth of arms can be deduced for P. stenopetalus $\mathrm{n}$. sp. At the beginning, they grew both in height and width, but after the third branch, they only increased in height.

This new species clearly differs from other genera in arm form and arrangement of ambulacral grooves. Fused brachials are planate with a very small angle, and ambulacral grooves are rectilinear and only on the oral surface.

Genus Sinopetalocrinus Mu and Lin, 1987 Figures 4, 5.1-5.5, 6

Type species.—Sinopetalocrinus involutus Mu and Lin, 1987.

Sinopetalocrinus involutus Mu and Lin, 1987 Figure 4

1987 Sinopetalocrinus involutus $\mathrm{Mu}$ and Lin, p. 12, pl. 5, figs. 5-8.

Holotype.-Holotype NIGP 73967.

Diagnosis.—As many as 32-40 distal ambulacra; distal part of arms with a rolled margin; adjacent arms not in lateral contact; ambulacral grooves on oral and aboral surface; ambulacra coverage on aboral surface is $>50 \%$.

Occurrence.-Leijiatun Formation, Aeronian (Llandovery, Silurian), Sigou section, Shiqian County, Guizhou Province, China; Leijiatun Formation, Aeronian (Llandovery, Silurian), Fengxiang section, Shiqian County, Guizhou Province, China. NIGP 73967, NIGP 73968, NIGP 73969 and NIGP 73970 are type specimens of Sinopetalocrinus involutus from Mu and Lin (1987). NIGP 163729 is a new specimen from the Fengxiang section.

Description.-Ventral side slightly convex. Ambulacra coverage on aboral surface is $>50 \%$. Area of the aboral surface with ambulacra is $23.6 \mathrm{~mm}$ in height, $26.8 \mathrm{~mm}$ in width. Thus, the width is larger than the height. Aboral area lacking ambulacra and aboral area with ambulacra are $5.0 \mathrm{~mm}$ and $7.9 \mathrm{~mm}$ in thickness, respectively. The arm angle is $101^{\circ}$. Ambulacral grooves as many as 33, both on oral surface and aboral surface. Grooves $\sim 1 \mathrm{~mm}$ wide. The ridge width is equal to the ambulacral groove width. Flat ridge top. Unclear notch for ambulacral cover plates on NIGP 163729. Well-preserved, horseshoeshaped facet $4.4 \mathrm{~mm}$ in width, $3.0 \mathrm{~mm}$ in depth.

Materials.-Paratypes NIGP 73968, NIGP 73969 and NIGP 73970; other material: NIGP 163729. 

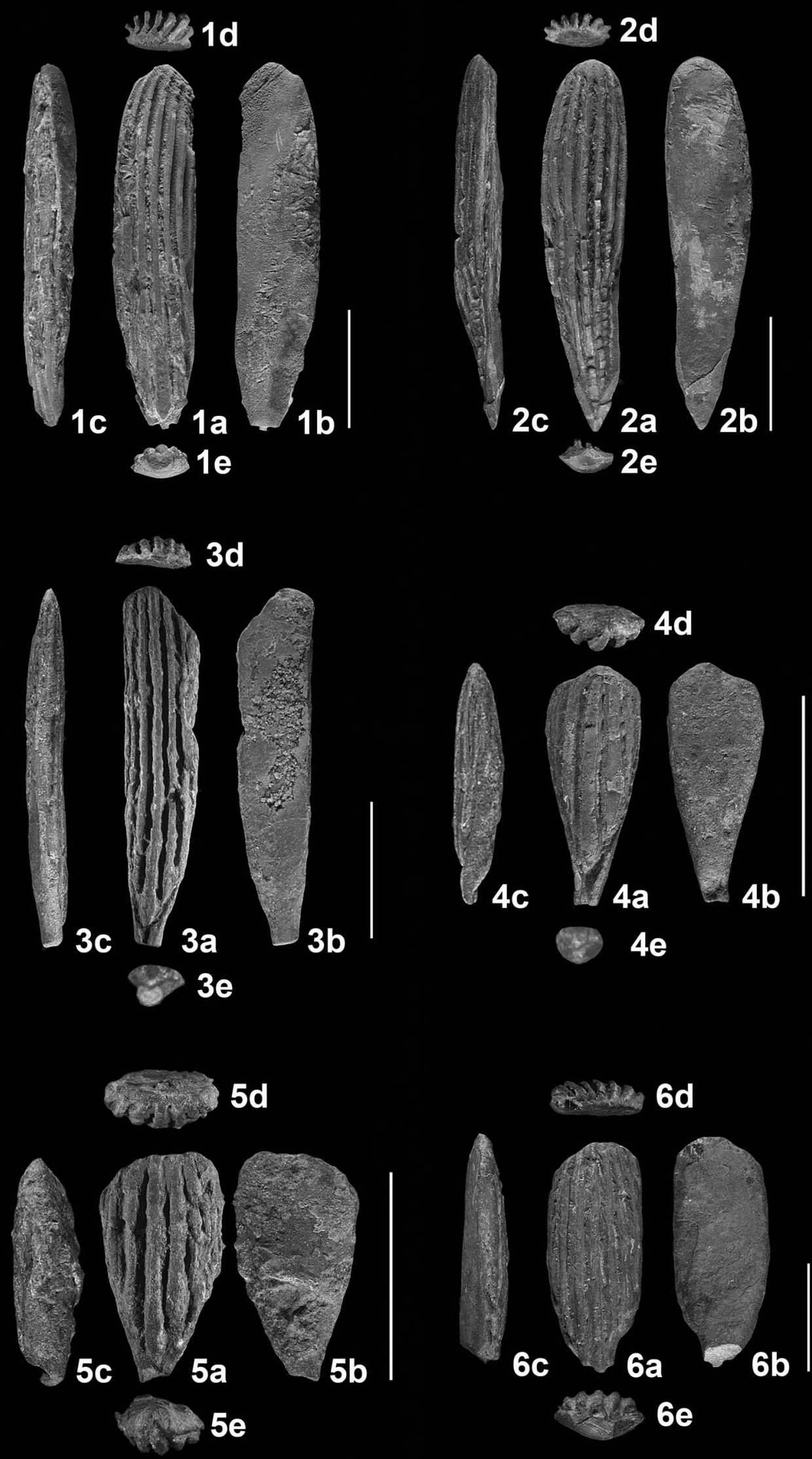

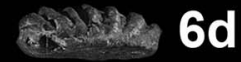

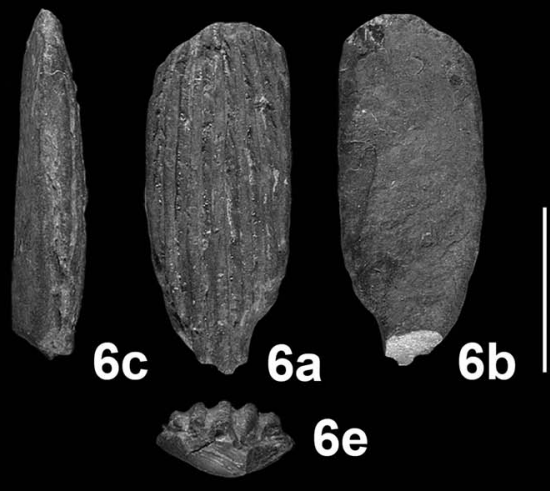


Remarks.-The arms first fused laterally as in Petalocrinus, and then the distal part rolled dorsally, forming an arm-roll. Only a small area in the proximal part of the dorsal surface is not covered by ambulacra. The characters of the ventral furrow ridges and the articular facet are similar to those of Petalocrinus (Mu and Lin, 1987).

The aboral area lacking ambulacra of this species is less than half of the aboral side of the arm, which is larger than Sinopetalocrinus robustus but smaller than Sinopetalocrinus shiqianensis.

\section{Sinopetalocrinus shiqianensis $\mathrm{Mu}$ and Lin, 1987} Figure 5.1-5.5

1987 Sinopetalocrinus shiqianensis $\mathrm{Mu}$ and Lin, p. 12, pl. 5, figs. 1-4.

Holotype.-Holotype NIGP 73963.

Diagnosis.—As many as 32-35 distal ambulacra; distal part of arms with a rolled margin; adjacent arms not in lateral contact; ambulacral grooves on oral and aboral surface; ambulacra coverage on aboral surface is approximately one-third.

Occurrence.-Leijiatun Formation, Aeronian (Llandovery, Silurian), Sigou section, Shiqian County, Guizhou Province, China; Leijiatun Formation, Aeronian (Llandovery, Silurian), Fengxiang section, Shiqian County, Guizhou Province, China. NIGP 73963, NIGP 73964, NIGP 73965 and NIGP 73966 are type specimens of Sinopetalocrinus shiqianensis from $\mathrm{Mu}$ and Lin (1987). NIGP 163730 is a new specimen from the Fengxiang section. Aboral side of arm slightly convex.

Description.-Ambulacra coverage on aboral surface is approximately one-third. Area of aboral surface with ambulacra is $19.2 \mathrm{~mm}$ in height, $22.4 \mathrm{~mm}$ in width. Arm thickness is $6.0 \mathrm{~mm}$ where aboral side of arm lacks ambulacra and $7.0 \mathrm{~mm}$ where the aboral surface has ambulacral. The arm angle is $105^{\circ}$. Ambulacral grooves $\sim 1 \mathrm{~mm}$ wide, which is narrower than the ridge. Flat ridge top. The distal grooves as many as 32 . Unclear notch for ambulacral cover plates on NIGP 163730. Well-preserved, horseshoeshaped facet $2.5 \mathrm{~mm}$ in width, and $1.6 \mathrm{~mm}$ in depth.

Materials.-Paratypes NIGP 73964-73966; other material: NIGP 163730.

Remarks.-The aboral area lacking ambulacra in this species is larger than in Sinopetalocrinus involutus and Sinopetalocrinus robustus.

\section{Sinopetalocrinus robustus $\mathrm{Mu}$ and Lin, 1987} Figure 6

1987 Sinopetalocrinus robustus $\mathrm{Mu}$ and Lin, p. 12, pl. 6, figs. 1-3.
Holotype.-Holotype NIGP 73971.

Diagnosis.—As many as 33 distal ambulacra; distal part of arms with a rolled margin; adjacent arms not in lateral contact; ambulacral grooves on oral and aboral surface; percentage of ambulacra coverage on aboral surface is very high, only a very small area lack of ambulacra.

Occurrence.-Leijiatun Formation, Aeronian (Llandovery, Silurian), Sigou section, Shiqian County, Guizhou Province, China; Leijiatun Formation, Aeronian (Llandovery, Silurian), Fengxiang section, Shiqian County, Guizhou Province, China. NIGP 73971, NIGP 73972 and NIGP 73973 are type specimens of Sinopetalocrinus shiqianensis from Mu and Lin (1987). NIGP 163731 is a new specimen from the Fengxiang section.

Description.-Aboral side of arm slightly convex. Percentage of ambulacra coverage on aboral surface is very high, only a very small area lack of ambulacra. Aboral arm surface with ambulacra is relatively small with a height of $14.3 \mathrm{~mm}$ and width of $12.1 \mathrm{~mm}$. Thickness of aboral surface of arm that lacks ambulacra $2.8 \mathrm{~mm}$. Distal area of aboral surface with ambulacra is $4.7 \mathrm{~mm}$ in thickness. The arm angle is $118^{\circ}$. Ambulacral groove $\sim 1 \mathrm{~mm}$ wide and ridge $<1 \mathrm{~mm}$. As many as 33 ambulacral grooves on the distal arm. Unclear notch for ambulacral cover plates. Well-preserved, horseshoe-shaped facet $3.0 \mathrm{~mm}$ in width and $2.0 \mathrm{~mm}$ in height.

Materials.-Paratypes NIGP 73972 and NIGP 73973; other material: NIGP 163731.

Remarks.-This species is characterized by small and thin arm plates; a very small area of the aboral surface that lacks ambulacra; and many ambulacral grooves separated by narrow ridges.

Genus Spirocrinus $\mathrm{Mu}$ and Wu, 1974

Type species.-Spirocrinus typicus $\mathrm{Mu}$ and $\mathrm{Wu}, 1974$.

Other species.—Spirocrinus longus $\mathrm{Mu}$ and $\mathrm{Wu}, 1974$.

Spirocrinus longus $\mathrm{Mu}$ and $\mathrm{Wu}, 1974$

Figure 5.6

1974 Spirocrinus longus $\mathrm{Mu}$ and Wu, p. 208, pl. 97, figs. 6-8. 1987 Spirocrinus longus; Mu and Lin, p. 13, pl. 6, figs. 8-15.

Materials.-NIGP 163732.

Occurrence.-Shihniulan Formation, Aeronian (Llandovery, Silurian), Shuibatang section, Guizhou Province, China.

Remarks.-Arm cylindrical in shape and relatively high, but ambulacra only spiral around half of arm circumference. Arm $31.5 \mathrm{~mm}$ in height and $4.8 \mathrm{~mm}$ in width. Fused brachials

Figure 3. Petalocrinus stenopetalus n. sp.: (1) holotype, NIGP 163723; (2) paratype, NIGP 163724; (3) paratype, NIGP 163725; (4) NIGP 163726, juvenile specimen; (5) NIGP 163727; (6) NIGP 163728. a, oral side of arm plate; b, aboral side of arm plate; c, lateral view of arm plate; d, front view of distal furrows; $\mathrm{e}$, facet view of arm plate. Scale bars $=1 \mathrm{~cm}$. 

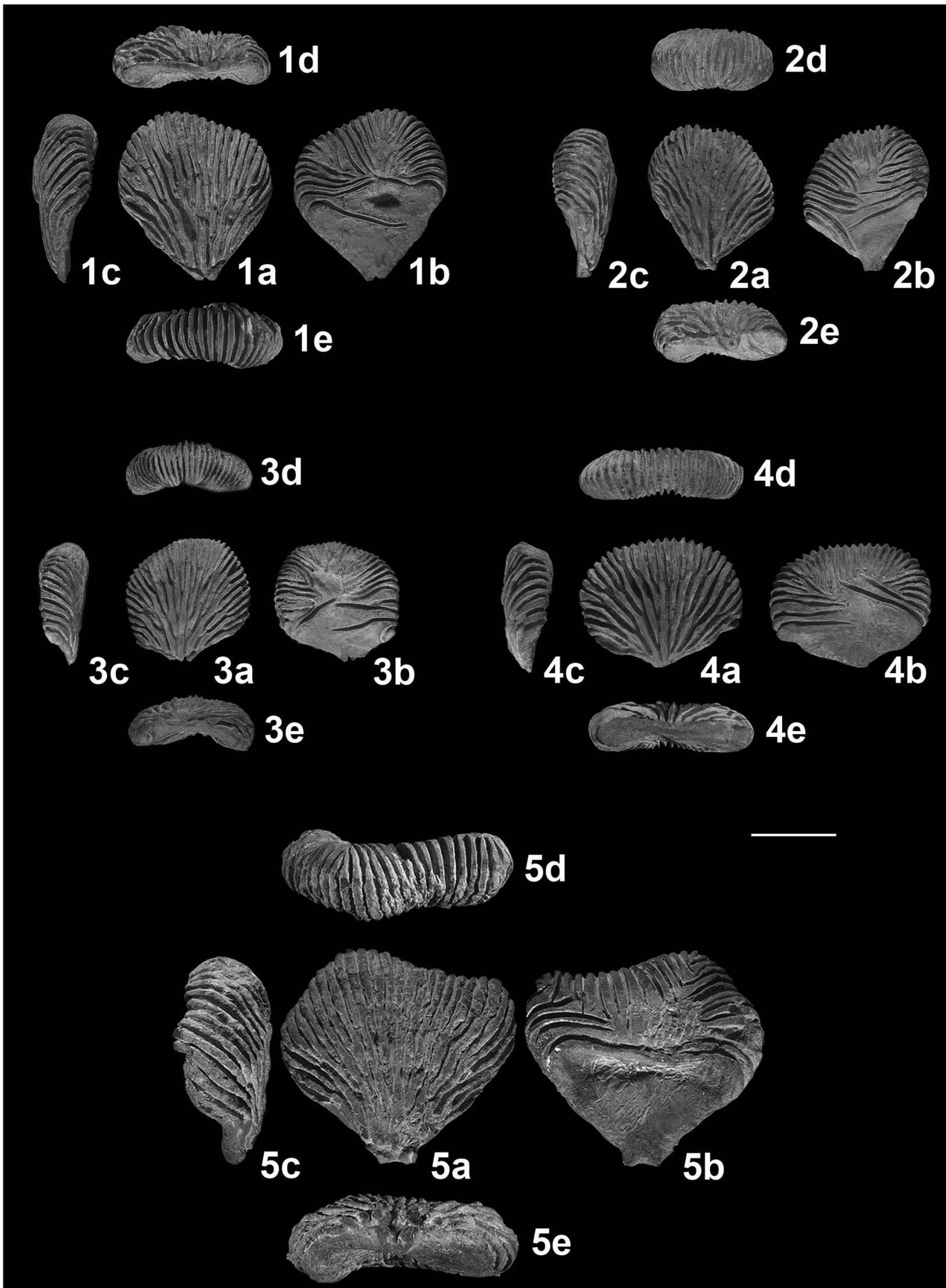

$5 e$

Figure 4. (1-5) Sinopetalocrinus involutus Mu and Lin, 1987, NIGP 73967, NIGP 73968, NIGP 73969, NIGP 73970 and NIGP 163729; a, oral side of arm plate; b, aboral side of arm plate; c, lateral view of arm plate; d, front view of distal furrows; e, facet view of arm plate. Scale bar $=1 \mathrm{~cm}$. 

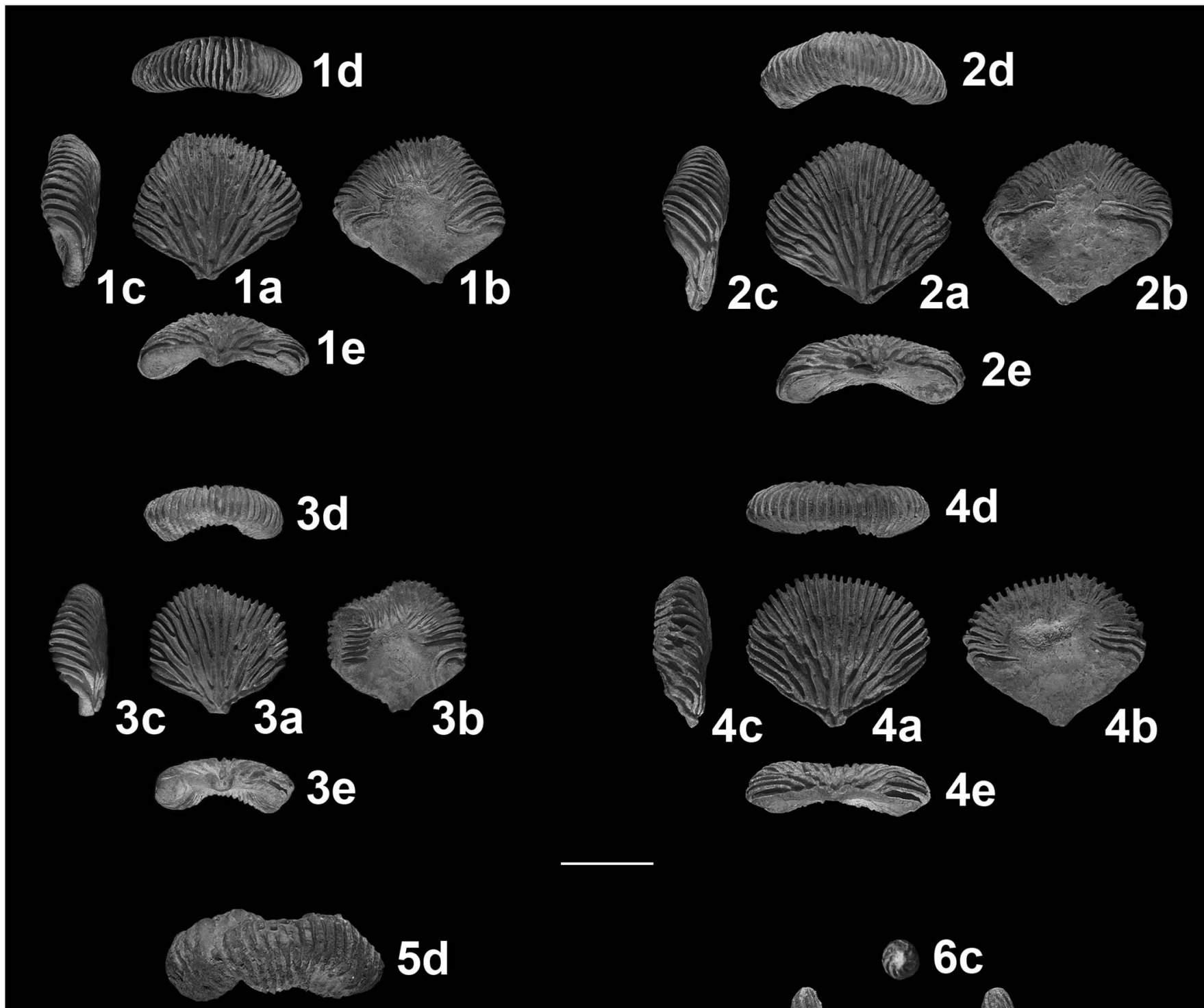

$5 d$

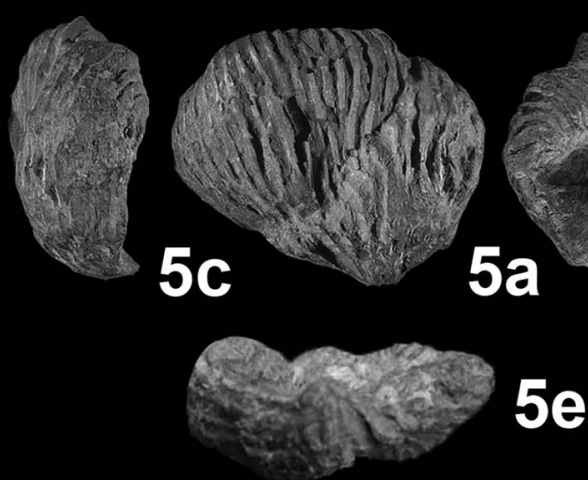

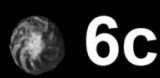

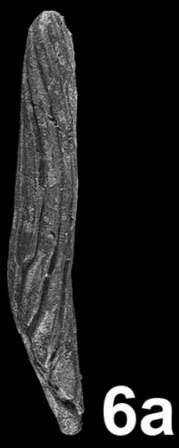

\section{6d}

Figure 5. (1-5) Sinopetalocrinus shiqianensis Mu and Lin, 1987, NIGP 73963, NIGP 73964, NIGP 73965, NIGP 73966 and NIGP 163730 ; a, oral side of arm plate; $b$, aboral side of arm plate; $c$, lateral view of arm plate; $d$, front view of distal furrows; e, facet view of arm plate. (6) Spirocrinus longus, NIGP 163732; a, left-lateral view of arm plate; $b$, right-lateral view of arm plate; $c$, front view of distal furrows; $d$, facet view of arm plate. Scale bar $=1 \mathrm{~cm}$.

tapered at both ends, as many as nine distal ambulacra. From left-lateral view, the left half of arm plate branches four times yielding five ambulacral grooves. From right-lateral view, the right half of arm plate branches three times yielding four ambulacral grooves. Well-preserved, horseshoe-shaped articular facets $2.6 \mathrm{~mm}$ in depth and $1.7 \mathrm{~mm}$ in width.

The six species of Spirocrinus are from the Leijiatun and Shihniulan formations, with left-hand spiraling taxa endemic to 


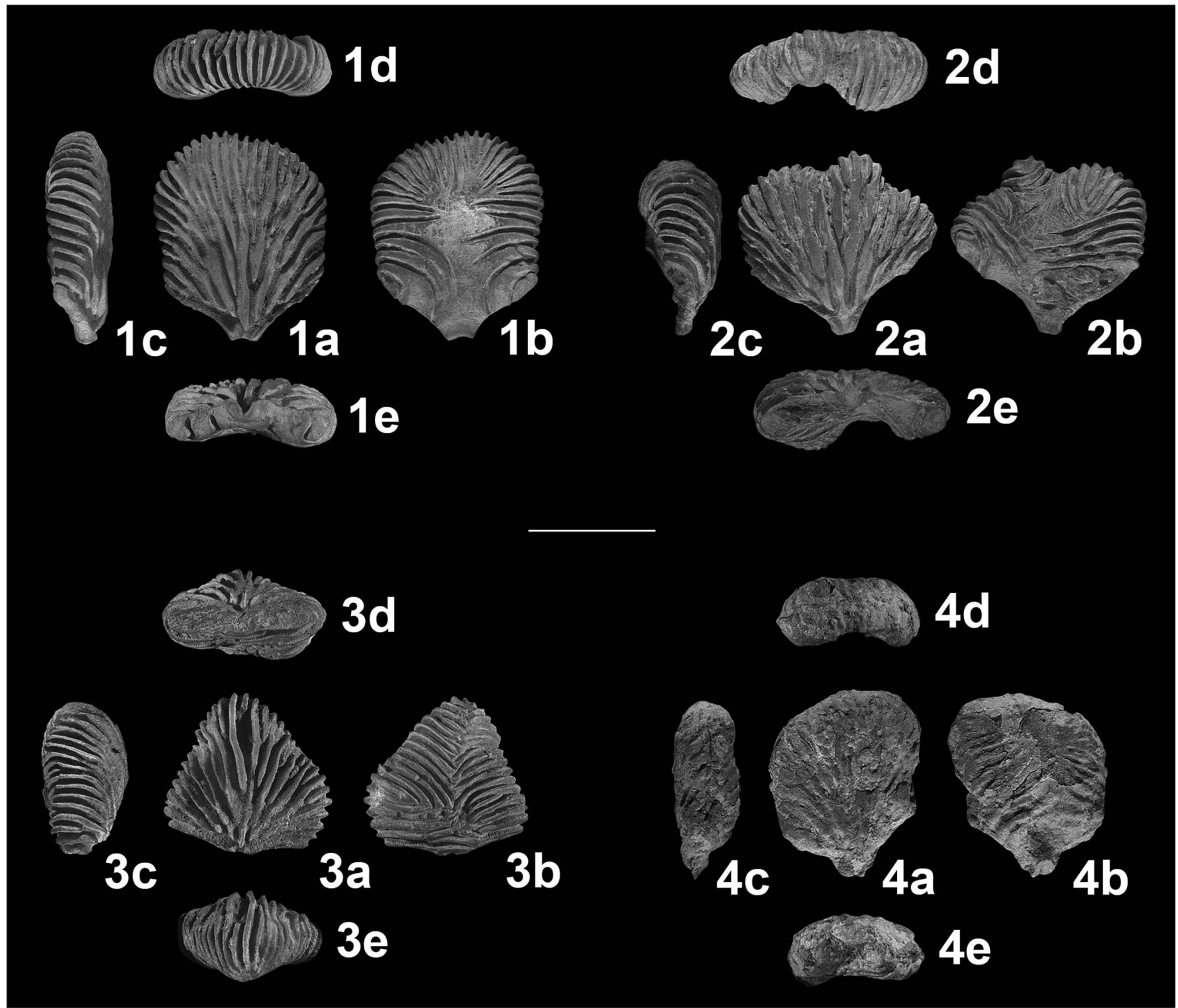

Figure 6. (1-4) Sinopetalocrinus robustus Mu and Lin, 1987, NIGP 73971, NIGP 73972, NIGP 73973 and NIGP 163731; a, oral side of arm plate; b, aboral side of arm plate; c, lateral view of arm plate; d, front view of distal furrows; e, facet view of arm plate. Scale bar $=1 \mathrm{~cm}$.

the Upper Yangtze Epicontinental Sea (Mu and Wu, 1974; Mu and Lin, 1987; Mao et al., 2013).

Spirocrinus circularis new species

Figure 7

Holotype.-Holotype NIGP 163733.

Occurrence.-Shihniulan Formation. Aeronian (Llandovery, Silurian), Shuibatang section, Tongzi County, Guizhou, China.
Diagnosis.-As many as 6-8 distal ambulacra endotomously branched but not spiraled. Both sides of the ambulacra branch toward the dorsal side until ambulacra from each side abut one another.

Description.-Fused brachials cylindrical and tapered at both ends, and adjacent arms not in lateral contact. Linear axis. The six specimens vary in size. Three type specimens (NIGP 163733-162735) of $29.4 \mathrm{~mm}, 26.7 \mathrm{~mm}$, and $25.5 \mathrm{~mm}$ in height, respectively; $4.6 \mathrm{~mm}, 4.3 \mathrm{~mm}$, and $4.6 \mathrm{~mm}$ in maximum diameter, respectively. Additional specimens are NIGP 163736

Figure 7. Spirocrinus circularis n. sp.: (1) holotype, NIGP 163733; (2) paratype, NIGP 163734; (3) paratype, NIGP 163735; (4) NIGP 163736; (5) NIGP 163737; (6) NIGP 163738. a, oral side of arm plate; b, aboral side of arm plate; c, right-lateral view of arm plate; d, left-lateral view of arm plate; e, front view of distal furrows; $f$, facet view of arm plate. Scale bar $=1 \mathrm{~cm}$. 


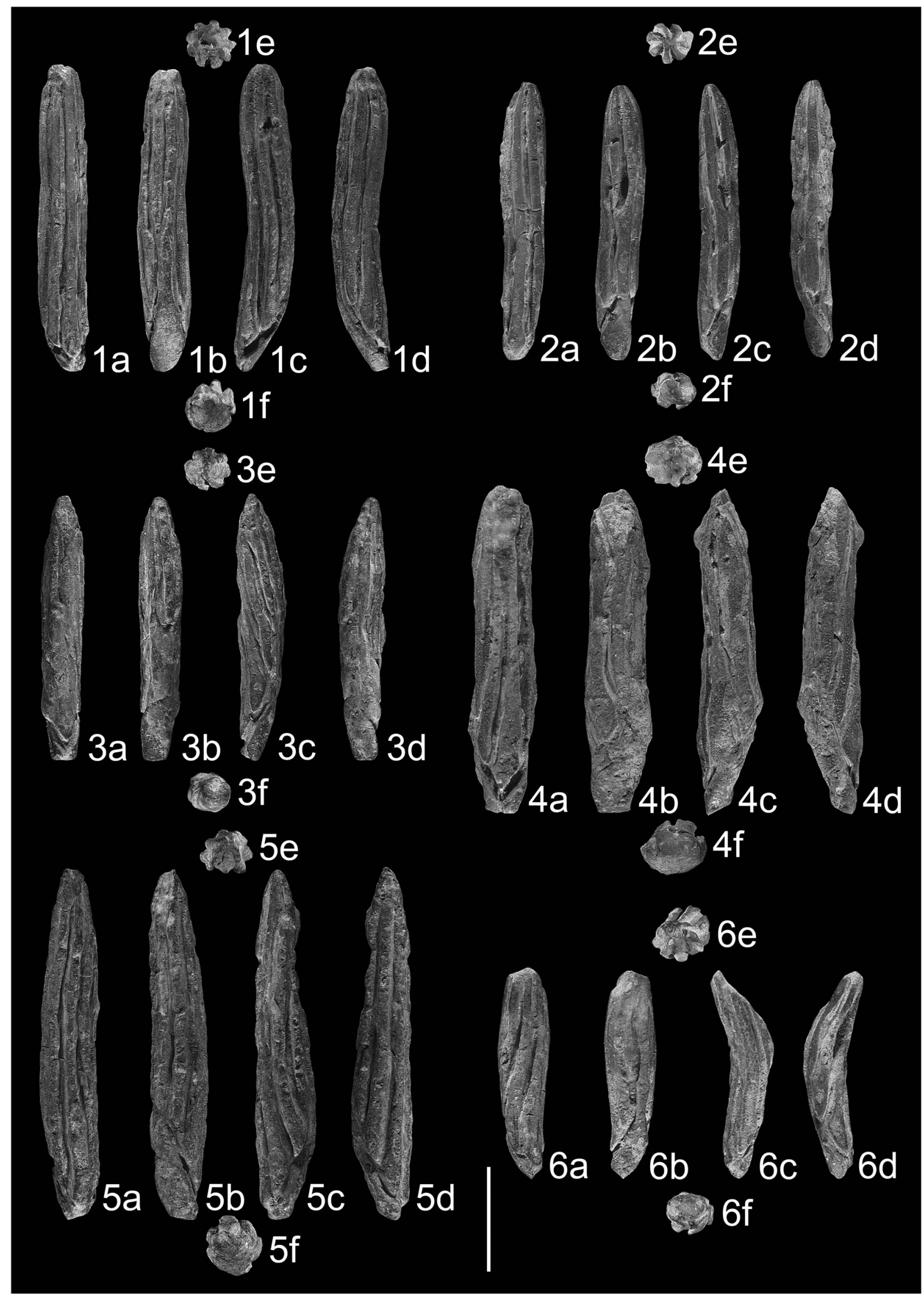


and NIGP 163737 that are $31.4 \mathrm{~mm}$ and $33.8 \mathrm{~mm}$ in height, respectively; $6.7 \mathrm{~mm}$ and $5.4 \mathrm{~mm}$ in maximum diameter, respectively. A smaller specimen, NIGP 163738 , is $20.0 \mathrm{~mm}$ in height and $4.7 \mathrm{~mm}$ in maximum diameter.

The ambulacral grooves branch no more than three times with 6-8 distal ambulacral grooves endotomously branched but not spiraled, no branching in the middle of the arm. NIGP 163733 and 162735-162738 have eight distal grooves, and NIGP 163734 has seven distal grooves with a width of $\sim 1 \mathrm{~mm}$, which is equal to that of a ridge between adjacent ambulacral grooves. The dorsal central ridges between ambulacra are wider proximally. The notches for ambulacral cover plates alternating on either side, and although poorly preserved are present on NIGP 163733 and NIGP 163734. Well-preserved, horseshoeshaped proximal facets from six specimens generally have a width between $2.5 \mathrm{~mm}$ and $3.3 \mathrm{~mm}$ and a depth from $1.4 \mathrm{~mm}$ to $2.0 \mathrm{~mm}$.

Etymology.-The species name "circularis" is in reference to the endotomously branched but not spiraling distal ambulacra on the cylindrical arms.

Materials.-Paraypes NIGP 163734 and NIGP 163735; other materials: NIGP 163736-163738.

Remarks.-This species differs markedly from other species of the genus in having endotomously branched ambulacral grooves on the cylindrical fused arm plate with no spiraling. Therefore, this morphology is a significant evolutionary link between Petalocrinus and Spirocrinus in aspects of length, branching mode, and number of distal ambulacral grooves, somewhat similar to those of Petalocrinus stenopetalus n. sp. Thus as discussed below, Spirocrinus circularis n. sp. is considered a descendant of Petalocrinus stenopetalus $\mathrm{n}$. sp. or a similar form.

\section{Spirocrinus dextrosus new species}

Figure 8

\section{Holotype.-Holotype NIGP 163739.}

Occurrence.-Shihniulan Formation. Aeronian (Llandovery, Silurian), Shuibatang section, Tongzi County, Guizhou, China.

Diagnosis.-As many as 7-10 distal ambulacra, adjacent arms not in lateral contact, ambulacral grooves spiraled one cycle around fused arm with right-handed spiral.

Description.-Fused brachials cylindrical and tapered at both ends; adjacent arms not in lateral contact; ambulacra with righthanded spiral. The six specimens vary greatly in sizes. Three type specimens (NIGP 163739-163741) are $21.8 \mathrm{~mm}, 25.0 \mathrm{~mm}$, and $23.4 \mathrm{~mm}$ in height; $4.2 \mathrm{~mm}, 5.2 \mathrm{~mm}$, and $5.2 \mathrm{~mm}$ in maximum diameter, respectively. Larger NIGP 163742-163044 are $28.3 \mathrm{~mm}, 30.1 \mathrm{~mm}$, and $32.9 \mathrm{~mm}$ in height; $6.0 \mathrm{~mm}, 6.0 \mathrm{~mm}$, and $5.6 \mathrm{~mm}$ in maximum diameter, respectively.

The ambulacral grooves branch no more than three times with 7-10 distal ambulacral grooves, no branching in the middle of the arm, yielding ten distal ambulacra. All specimens with the same branching pattern. NIGP 163739-163742 and 163744 have eight distal ambulacral grooves and NIGP 163743 has nine. The width of the groove is $\sim 1 \mathrm{~mm}$ and is spiraled one cycle around the fused arm with a right-handed spiral. The groove width equals that of the ridge width, which is generally flattened. The notches for ambulacral cover plates are not very clear. The proximal horseshoe-shaped arm facet is well preserved in five specimens (NIGP 163739-163743), although part of the facet has been broken away in NIGP 163744. Facets are $1.5-3.4 \mathrm{~mm}$ in width and $1.4-2.4 \mathrm{~mm}$ in depth.

Etymology.-The species name 'dextrosus' recognizes the right-spiraled ambulacra of Spirocrinus described from China.

Materials.-Paratypes NIGP 163740 and NIGP 163741; other materials: NIGP 163742-163744.

Remarks.-The notable characteristic of the species is the rightspiraled direction of the ambulacral grooves. Other reported species have an ambulacrum with a left-handed ambulacral spiral or an ambulacrum without spiraling. In addition to the direction of the spiral, there is little difference between this species and other left-handed species. Thus, Spirocrinus dextrosus n. sp. also originated from Spirocrinus circularis n. sp., but has the opposite spiraled direction.

\section{Evolution of the Petalocrinidae}

With only second-primibrachial characters known for all taxa, an insufficient number of characters exists to complete a comprehensive phylogenetic analysis of petalocrinid species. A small phylogenetic analysis is presented (Fig. 9) only to explore the potential morphological pathways that led to Silurian genera. Whereas this analysis elucidates morphological trends, it cannot be used to develop a phylogenetic classification of petalocrinid species and genera.

Li (1993) described the Middle Ordovician petalocrinid Eopetalocrinus and hypothesized potential evolutionary trends among Eopetalocrinus, Petalocrinus, and Sinopetalocrinus. Petalocrinidae evolutionary history was also discussed briefly in Mao et al. (2015). The discovery of the new species described herein allows a more detailed understanding of Petalocrinidae evolution.

Following the Late Ordovician mass extinction, crinoid biodiversity recovered to pre-extinction levels by the Aeronian (middle Llandovery) (Peters and Ausich, 2008). This was accompanied by a rise in sea level with the waning of the Late Ordovician-early Silurian glaciations. As suggested by Fearnhead and Harper (2007), this rise in sea level reestablished epicontinental seas and promoted faunal migrations. A global distribution of Petalocrinus occurred earlier than the typical cosmopolitan Wenlockian faunas (Witzke et al., 1979). During the Llandovery, Petalocrinus first occurred on the Laurentia paleocontinent (Mulloch Hill Formation, Scotland, Rhuddanian; Fearnhead and Harper, 2007). By the Wenlock, Petalocirnus was present on the South China Block, Laurentia, Baltica, and Avalonia paleocontinents (Mao et al., 2015).

The highest genus-level biodiversity occurred during the Llandovery in the Upper Yangtze region of China, with the co-occurrence of Petalocrinus, Sinopetalocrinus, and Spirocrinus, 

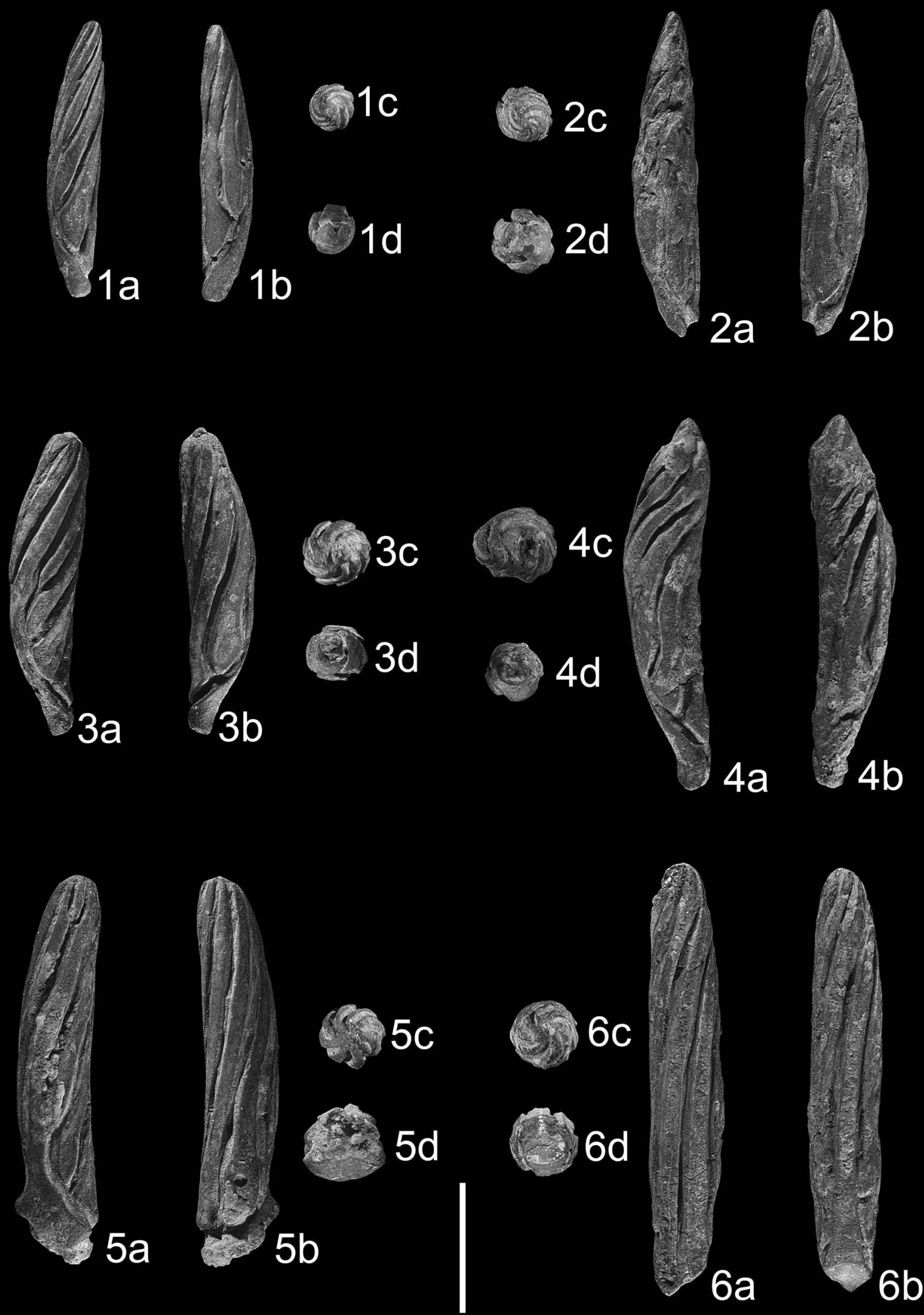

Figure 8. Spirocrinus dextrosus n. sp.: (1) holotype, NIGP 163739; (2) paratype, NIGP 163740; (3) paratype, NIGP 163741; (4) NIGP 163742; (5) NIGP 163743; (6) NIGP 163744. a, left-lateral view of arm plate; b, right-lateral view of arm plate; c, front view of distal furrows; $\mathrm{d}$, facet view of arm plate. Scale bar $=1 \mathrm{~cm}$. 


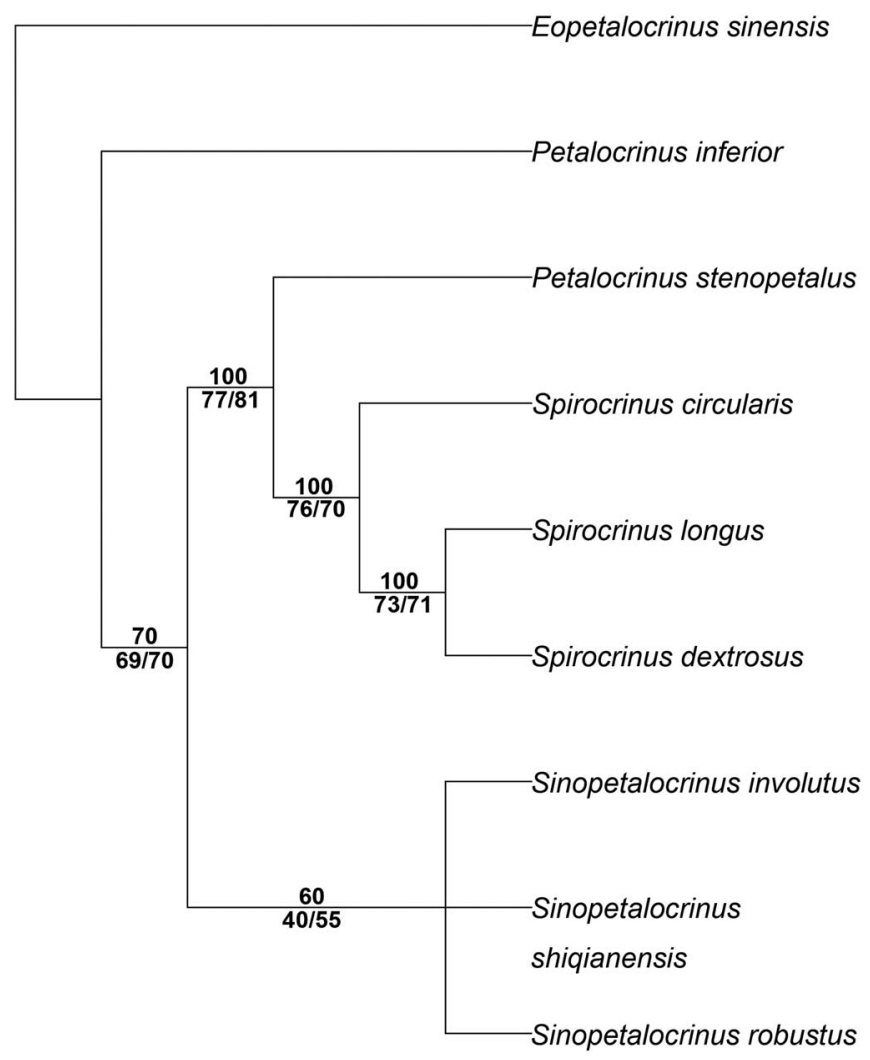

Figure 9. Phylogenic tree representing the relationship among genera of petalocrinids from China. The cladogram corresponds to the 50\% majority-rule tree of 10 trees, with majority-rule values above and bootstrap/jackknife support below at bifurcations. Tree length $=18, \mathrm{CI}=0.889, \mathrm{RI}=0.895$, and $\mathrm{RC}=0.795$.

the latter two endemic to the South China Block. After the Llandovery the Petalocrinidae had a much lower morphologic disparity globally with the final two species of Petalocrinus occurring in the Wenlock of Laurentia and Baltica. Finally, the Early Devonian petalocrinid, Vadarocrinus of the Perunica paleocontinent, occurred in the present-day Czech Republic and is the youngest known occurrence of the Petalocrinidae. It is still unknown why there are two long-term durations, Darriwilian-Hirnantian and Ludlow-earliest Devonian, that lack representatives of this family.

Petalocrinus evolved from the Ordovician crinoid Eopetalocrinus by a change from having the arms (second primibrachials) in lateral contact, nearly forming a solid plate to second primibrachials with the lateral edges concave, yielding gaps between adjacent arms. Two distinct lineages evolved from the basic Petalocrinus morphology (Fig. 9). Petalocrinus stenopetalus n. sp. retained planar second primibrachials, but it evolved narrow and elongate second primibrachials compared to other species of Petalocrinus (Fig. 3). This change in shape produced a much less dense filtration fan, but the length of the total ambulacra remained approximately the same. From P. stenopetalus n. sp., Spirocrinus evolved a circular cross-sectional shape for the second primibrachials, and the ambulacra extended around the circumference of the arm plate (Figs. 7-9). Like P. stenopetalus n. sp., the Spirocrinus second primibrachials are much higher than those of a typical Petalocrinus, and the length of the total ambulacra remained approximately the same. From a strict phylogenetic perspective (Fig. 9), P. stenopetalus $\mathrm{n}$. sp. could be placed in Spirocrinus. However, as noted above, the analysis depicted in Figure 9 does not include enough taxa to allow confident phylogenetic conclusions. Further, from a Linnaean, rank-based perspective, $P$. stenopetalus $\mathrm{n}$. sp. has all of the diagnostic characters of Petalocrinus and lacks diagnostic characters of Spirocrinus. Thus, for the present, $P$. stenopetalus n. sp. is retained in Spirocrinus.

Sinopetalocrinus species form a monophyletic group derived from Petalocrinus inferior, a sister group of P. stenopetalus $\mathrm{n}$. $\mathrm{sp}$. and the Spirocrinus species used in this analysis (Fig. 9). Based on current analysis, Petalocrinus should be regarded as a paraphyletic genus until a more comprehensive species-level phylogeny can be attempted.

As noted in Mao et al. (2015), this arm morphology may have been an adaptation to the multidirectional flow conditions present in a reefal setting. Also, on Spirocrinus arms, the ambulacral groove was much wider than on species of either Petalocrinus or Sinopetalocrinus, which is an indication that Spirocrinus individuals fed on a wider range of food sizes (Ausich, 1980). Alternatively, a more typical Petalocrinus species (e.g., P. inferior) evolved into Sinopetalocrinus by the expansion of the ambulacra from only the aboral surface to both the oral and aboral surfaces (Figs. 4-6, 9). The increased length of the ambulacra on an arm allowed particle capture on both the oral and aboral sides of the arm (Mao et al., 2015). Again, this configuration may be better adapted to the multidirectional flow conditions present in a reefal setting.

\section{Conclusions}

Members of Silurian Petalocrinidae occur in carbonate facies of the Upper Yangtze Epicontinental Sea and are especially common from the coeval Shihniulan and Leijiatun formations. Three new taxa are described that further our understanding of the phylogenetic relationships within the Petalocrinidae. Petalocrinus stenopetalus n. sp. and Spirocrinus circularis n. sp. are key transitional taxa that allow us to establish a definite evolutionary trend from Petalocrinus to Spirocrinus. Genus and species divergences happened within a very short time during the Llandovery of China. Thereafter, when Petalocrinus became cosmopolitan, the pace of speciation was considerably slower, and no new genera arose during the Silurian.

\section{Acknowledgments}

This research was supported by National Natural Science Foundation of China (granted No. $\beta 2022$, XDB10010503) and the National Science Foundation (WIA, DEB 1036416). We offer our sincere gratitude to J. Jin and S. Zamora for editing, and two reviewers for the very useful comments on the earlier version of the manuscript.

\section{References}

Ausich, W.I., 1980, A model for niche differentiation in Lower Mississippian crinoid communities: Journal of Paleontology, v. 54, p. 273-288.

Ausich, W.I., 1984a, Calceocrinids from the early Silurian (Llandoverian) Brassfield Formation of southwestern Ohio: Journal of Paleontology, v. 58, p. 1167-1185.

Ausich, W.I., 1984b, The genus Clidochirus from the early Silurian of Ohio (Crinoidea, Llandoverian): Journal of Paleontology, v. 58, p. 1341-1346. 
Ausich, W.I., 1985, New crinoids and revision of the superfamily Glyptocrinacea (early Silurian, Ohio): Journal of Paleontology, v. 59, p. 793-808.

Ausich, W.I., 1986a, New camerate crinoids of the suborder Glyptocrinina from the lower Silurian Brassfield Formation (southwestern Ohio): Journal of Paleontology, v. 60, p. 887-897.

Ausich, W.I., 1986b, Early Silurian inadunate crinoids (Brassfield Formation, Ohio): Journal of Paleontology, v. 60, p. 719-735.

Ausich, W.I., 1986c, Early Silurian rhodocrinitacean crinoids (Brassfield Formation, Ohio): Journal of Paleontology, v. 60, p. 84-106.

Ausich, W.I., 1986d, Palaeoecology and history of the Calceocrinidae (Palaeozoic Crinoidea): Palaeontology, v. 29, p. 85-99.

Ausich, W.I., 1987a, Brassfield Compsocrinina (early Silurian crinoids) from Ohio: Journal of Paleontology, v. 61, p. 552-562.

Ausich, W.I., 1987b, Revisions of Rowley's Ordovician (?) and Silurian crinoids from Missouri: Journal of Paleontology, v. 61, p. 563-578.

Ausich, W.I., and Copper, P., 2010, The Crinoidea of Anticosti Island, Québec (late Ordovician to early Silurian): Palaeontographica Canadiana, v. 29, p. 157.

Ausich, W.I., and Dravage, P., 1988, Crinoids from the Brassfield Formation of Adams County, Ohio: Journal of Paleontology, v. 62, 285-289.

Ausich, W.I., Peter, M.E., and Ettensohn, F.R., 2015, Echinoderms from the lower Silurian Brassfield Formation of east-central Kentucky: Journal of Paleontology, v. 89 , p. 245-256.

Bather, F.A., 1898, Petalocrinus, Weller \& Davidson: The Quarterly Journal of the Geological Society of London, v. 54, p. 401-441.

Bather, F.A., 1899, A phylogenetic classification of the Pelmatozoa: British Association for the Advancement of Science, v. 1898, p. 916-923.

Boyarko, D., and Ausich, W.I., 2009, New calceocrinids from the Brassfield Formation of northern Kentucky and southern Ohio: Southeastern Geology, v. 46 , p. $103-108$

Chen, X., et al., 1996, Telychian (Llandovery) of the Yangtze region and its correlation with British Isles: Beijing, Science Press, p. 1-162. (in Chinese)

Chen, Z.T., and Yao, J.H., 1993, Palaeozoic Echinoderm Fossils of Western Yunnan, China: Beijing, Geological Publishing House, 102 p. (in Chinese)

Donovan, S.K., 1993, A Rhuddanian (Silurian, lower Llandovery) pelmatozoan fauna from south-west Wales: Geological Journal, v. 28, p. 1-19.

Donovan, S.K., and Harper, D.A.T., 2003, Llandovery Crinoidea of the British Isles, including description of a new species from the Kilbride Formation (Telychian) of western Ireland: Geological Journal, v. 38, p. 85-97.

Donovan, S.K., and Lewis, D.N., 2005, Upper Llandovery (Telychian) crinoids (Echinodermata) of Devil's Dingle, Buildwas, Shropshire: Geological Journal, v. 40, p. 343-350.

Donovan, S.K., and Sevastopulo, G.D., 1989, Myelodactylid crinoids from the Silurian of the British Isles: Palaeontology, v. 32, p. 689-710.

Donovan, S.K., Lewis, D.N., Crabb, P., and Widdison, R.E., 2008, A field guide to the Silurian Echinodermata of the British Isles: Part 2-Crinoidea, minor groups and discussion: Proceedings of the Yorkshire Geological Society, v. 57, p. $29-60$.

Donovan, S.K., Lewis, D.N., Fearnhead, F.E., and Widdison, R.E., 2009, The British Silurian Crinoidea, Part 1, Introduction and Disparida: Monographs of the Palaeontographical Society, London, v. 163, p. 51.

Donovan, S.K., Widdison, R.E., Lewis, D.N., and Fearnhead, F.E., 2010 , The British Silurian Crinoidea, Part 2, addendum to part 1 and Cladida: Monographs of the Palaeontographical Society, London, v. 164, p. 47-133.

Donovan, S.K., Lewis, D.N., Fearnhead, F.E., and Widdison, R.E., 2012, The British Silurian Crinoidea, Part 3, addendum to parts 1 and 2, Camerata and columnals: Monographs of the Palaeontographical Society, London, v. 166, p. 135-259.

Eckert, J.D., 1984, Early Llandovery crinoids and stelleroids from the Cataract Group (lower Silurian), southern Ontario, Canada: Royal Ontario Museum Life Sciences, Contributions, v. 137, p. 1-83.

Eckert, J.D., 1990, The early Silurian myelodactylid crinoid Eomyelodactylus Foerste: Journal of Paleontology, v. 64, p. 135-141.

Eckert, J.D., and Brett, C.E., 2001, Early Silurian (Llandovery) crinoids from the Lower Clinton Group, western New York State: Bulletins of American Paleontology, v. 360, p. 1-88.

Fearnhead, F.E., and Donovan, S.K., 2007a, New crinoids (Echinodermata) from the Llandovery (Lower Silurian) of the British Isles: Palaeontology, v. 50, p. 905-915.

Fearnhead, F.E., and Donovan, S.K., 2007b, A cladid crinoid (Echinodermata) from the Llandovery (lower Silurian) of the Girvan district, SW Scotland: corrigendum: Scottish Journal of Geology, v. 43, p. 180.

Fearnhead, F.E., and Harper, D.A.T., 2007, Petalocrinus (Echinodermata, Crinoidea) from the Llandovery (Lower Silurian; Rhudannian) of the Girvan district, SW Scotland: Scottish Journal of Geology, v. 43, p. 69-74.

Guo, Y.H., Li, Z.F., Li, D.H., Zhang, T.M., Wang, Z.C., Yu, J.F., and Xi, Y.T., 2004, Lithofacies paleogeography of the Early Silurian in Sichuan area Journal of Paleogeography, v. 6, p. 20-29. (in Chinese with English abstract)

Lane, N.G., and Moore, R.C., 1978, Suborder Cyathocrinina Bather, 1899 , in Moore, R.C., and Teichert, C., eds., Treatise on Invertebrate
Paleontology Part T. Echinodermata 2. Crinoidea 2: Boulder $\mathrm{CO}$ and Lawrence KS, The Geological Society of America and University of Kansas Press, p. T578-T606.

Li, L.Z., 1993, Discovery of Eopetalocrinus (gen. nov.) in Lower Ordovician Dawan Formation at Liujiachang, Songzi, Hubei and its significance: Oiland Gas Geology, v. 14, p. 272-278. (in Chinese)

Li, Y., and Kershaw, S., 2003, Reef reconstruction after extinction event of Latest Ordovician in Yangtze Platform, South China: Facies, v. 48, p. 269-284.

Li, Y., Kershaw, S., and Chen, X., 2004, Control of carbonate sedimentation and reef growth in Llandovery sequences on the northwestern margin of Yangtze Platform, South China: Gondwana Research, v. 7, p. 937-949.

Ma, D.Z., Chen, H.D., Zhu, L.D., and Lin, L.B., 2006, Depositional system and lithofacies and paleogeography of the Silurian Shiniulan Formation in the southern Sichuan Basin, China: Journal of Chengdu University of Technology (Science \& Technology Edition), v. 33, p. 228-232. (in Chinese with English abstract)

Mao, Y.Y., Lin, J.P., and Li, X.F., 2013, New material of Petalocrinidae from northern Guizhou: Acta Geologica Sinica (English Edition), v. 87, (Suppl.), p. 886-888

Mao, Y.Y., Lin, J.P., Lin, C.H., and Ausich, W.I., 2015, Chinese origin and radiation of the Palaeozoic Crinoid Family Petalocrinidae: Palaeoworld, v. 24 , p. $445-453$

Miller, J.S., 1821, A Natural History of the Crinoidea, or Lily-shaped Animals; with Observations on the Genera, Asteria, Euryale, Comatula and Marsupites: Bristol, Bryan \& Co., 150 p.

Moore, R.C., and Laudon, L.R., 1943, Evolution and classification of Paleozoic crinoids: Geological Society of America Special Paper, v. 46, p. $1-151$

Mu, A.T., 1950 (1949), Petalocrinus from the Shihniulan Limestone of Wuchuan: Bulletin of the Geological Society of China, v. 29, p. 93-96.

Mu, A.T., and Wu, Y.R., 1974, Silurian Crinoidea. in Nanjing Institute of Geology and Paleontology of Chinese Academy of Sciences, ed A Handbook of the Stratigraphy and Paleontology of Southwest China: Beijing, Science Press, p. 208-210. (in Chinese)

Mu, E.Z. [Mu, A.T.], and Lin, C.H., 1987, Petalocrinidae from the Silurian of Shiqian District, Guizhou: Bulletin of Nanjing Institute of Geology and Paleontology, v. 12, p. 1-30. (in Chinese)

Ni, C., Deng, X.J., and Li, Y., 2015, Biodiversity of the 'Lungmachi Formation' limestones at the Xiangshuyuan Section, Shiqian, NE Guizhou Province, SW China: Acta Micropaleontological Sinica, v. 32, p. 96-104. (in Chinese with English abstract)

Peters, S.E., and Ausich, W.I., 2008, A sampling-adjusted macroevolutionary history for Ordovician-Silurian crinoids: Paleobiology, v. 34, p. 104-116.

Prokop, R.J., 1983 (1984), Vadarocrinus vassa gen. et sp. $\mathrm{n}_{\text {., (Crinoidea, Peta- }}$ locrinidae) from the Lower Devonian of Bohemia: Časopis Národního muzea, Řada Př́rodovědná, v. 152, p. 187-188.

Prokop, R.J., and Petr, V., 2010, New finds of Vadarocrinus vassa Prokop, 1984 (Crinoidea, Petalocrinidae) in the Koněprusy and Loděnice Limestones (Lower Devonian, Pragian) of the Barrandian area, Czech Republic: Journal of the National Museum (Prague), Natural History Series, v. 179 (14), p. $147-152$.

Roemer, C.F., 1852-1854, Erste Periode, Kohlen-Gebirge, in Bronn, H.G., ed., Lethaea Geognostica 1851-1856, Third Edition., Volume Two: Stuttgart, E. Schweizerbart, p. 210-291.

Rong, J.Y., and Chen, X., 2000, Comments on Silurian Chronostratigraphy of China: Journal of Stratigraphy, v. 24, p. 27-35. (in Chinese with English abstract)

Rong, J.Y., and Zhan, R.B., 2004, Niuchang Formation, a new lithostratigraphic unit of Llandovery (Silurian) from the Upper Yangtze Region: Journal of Stratigraphy, v. 28, p. 300-306. (in Chinese with English abstract)

Rong, J.Y., Chen, X., Su, Y.Z., Ni, Y.N., Zhan, R.B., and Chen, T.E., 2003 , Silurian paleogeography of China, in Landing, E., and Johnson, M.E., eds., Silurian Lands and Seas-Paleogeography Outside of Laurentia: New York State Museum Bulletin, v. 493, p. 243-298.

Swofford, D. L., 2002, PAUP*. Phylogenetic Analysis Using Parsimony (*and Other Methods). Version 4.0a142: Sinauer Associates, Sunderland, Massachusetts.

Tien, C.C., and Mu, A.T., 1955 (Second printing in 1957), Crinoidea, in Chen, X., et al., eds., Index Fossils of China, Invertebrates, Volume One: Beijing, Geological Publishing House, p. 89-95. (in Chinese)

Wang, G., Li, Y., Kershaw, S., and Deng, X.J., 2014, Global reef recovery after the end-Ordovician extinction: evidence from the late Aeronian coral-stromatoporoid reefs in South China: GFF, v. 136, p. 157-161.

Wang, G.X., Zhan, R.B., Percival, I.G., Huang, B., Li, Y., and Wu, R.C., 2015, Late Hirnantian (latest Ordovician) carbonate rocks and shelly fossils in Shiqian, northeastern Guizhou, Southwest China: Newsletters on Stratigraphy, v. 48 , p. 241-252. 
Weller, S., and Davidson, A.D., 1896, Petalocrinus mirabilis (n. sp.) and a new American fauna: The Journal of Geology, v. 4, p. 166-173.

Witzke, B.J., and Strimple, H.L., 1981, Early Silurian crinoids of eastern Iowa: Proceedings of the Iowa Academy of Science, v. 88, p. 101-137.

Witzke, B.J., Frest, T.J., and Strimple, H.L., 1979, Biogeography of the Silurian-Lower Devonian echinoderms, In: Gray, J., and Boucot, A.J., eds., Historical Biogeography, Plate Tectonics and the Changing Environment: Oregon State University Press, Corvallis, p. 117-129.

Yang, X.P., Zhang, B.M., and Liu, S.B., 2002, Origin and Reservoir Property of Silurian Carbona mud mound in Southern Sichuan Basin: Marine Origin Petroleum Geology, v. 7, p. 26-32. (in Chinese with English abstract)

Accepted 7 November 2016

\section{Appendices}

Appendix 1.- Characters for genera of the Petalocrinidae.

A. Adjacent arms in lateral contact: 0 , yes; 1 , not.

B. Shape of second primibrachial in oral view: 0, triangular; 1, narrow triangle; 2 , straight sides.

C. Cross-section shape: 0, flat; 1, circular.

D. Position of ambulacra: 0, oral only; 1, both aboral and oral surface.

E. Percentage of ambulacral coverage in aboral surface: $0,0 \%$; $1,0-33 \% ; 2,33-50 \% ; 3,50-90 \% ; 4,100 \%$.

F. Maximum number of ambulacra: $0,12-32 ; 1,>32 ; 2,6-12$.
G. Height/width ratio of second primibrachial: $0,<1.8 ; 1,>1.8$.

H. Ambulacra: 0, planar; 1, spiral.

I. Direction of spiral: 0, left-handed spiral (counterclockwise); 1, right-handed spiral (clockwise).

J. Morphology of ambulacra: 0, curved; 1, straight.

$\mathrm{K}$. Ambulacra branching pattern: 0, poor isotomy; 1, endotomy.

Appendix 2.-Character states for phylogenetic analysis of the Petalocrinidae.

\begin{tabular}{lcccccccccccc}
\hline & \multicolumn{11}{c}{ Characters } \\
\cline { 2 - 13 } Genera & A & B & C & D & E & F & G & H & I & J & K \\
\hline Eopetalocrinus sinensis & 0 & 0 & 0 & 0 & 0 & 0 & 0 & 0 & - & 0 & 0 \\
Petalocrinus inferior & 1 & 0 & 0 & 0 & 0 & 0 & 0 & 0 & - & 0 & 0 \\
Petalocrinus stenopetalus n. sp. & 1 & 1 & 0 & 0 & 0 & 2 & 1 & 0 & - & 1 & 1 \\
Sinopetalocrinus involutus & 1 & 0 & 0 & 1 & 2 & 1 & 0 & 0 & - & 0 & 0 \\
Sinopetalocrinus shiqianensis & 1 & 0 & 0 & 1 & 1 & 1 & 0 & 0 & - & 0 & 0 \\
Sinopetalocrinus robustus & 1 & 0 & 0 & 1 & 3 & 1 & 0 & 0 & - & 0 & 0 \\
Spirocrinus circularis n. sp. & 1 & 2 & 1 & 1 & 4 & 2 & 1 & 0 & - & 1 & 1 \\
Spirocrinus longus & 1 & 2 & 1 & 1 & 4 & 2 & 1 & 1 & 0 & 0 & 1 \\
Spirocrinus dextrosus n. sp. & 1 & 2 & 1 & 1 & 4 & 2 & 1 & 1 & 1 & 0 & 1 \\
\hline
\end{tabular}

